\title{
THE EFFECTS OF ALLOFERON (ALLOKIN) IN THE THERAPY OF METABOLIC SYNDROME (A PILOT STUDY)
}

\author{
N.A. Didkovsky ${ }^{1}$, I.K. Malashenkova1,2, J.V. Abakumova ${ }^{3}$, \\ D.P. Ogurtsov ${ }^{1,2}$, S.A. Krynskiy ${ }^{2}$, N.A. Hailov ${ }^{2}$, \\ E.I. Chekulaeva ${ }^{2}$, M.V. Mamoshina ${ }^{2}$ \\ ${ }^{1}$ FSBI FCRC of Physical-Chemical Medicine FMBA of Russia, Moscow, Russia; \\ ${ }^{2}$ NRC "Kurchatov Institute", Moscow, Russia; \\ ${ }^{3}$ Saratov branch of the Samara Medical University "Reaviz", Samara, Russia
}

\section{ЭФФЕКТЫ АЛЛОФЕРОНА (АЛЛОКИНА) \\ В ТЕРАПИИ МЕТАБОЛИЧЕСКОГО СИНДРОМА (ПИЛОТНОЕ ИССЛЕДОВАНИЕ)}

\author{
Н.А. Дидковский ${ }^{1}$, И.К. Малашенкова ${ }^{1,2}$, Ж.В. Авакумова \\ Д.П. Огурцов ${ }^{1,2}$, С.А. Крынский ${ }^{2}$ Н.А. Хайлов ${ }^{2}$, \\ Е.И. Чекулаева ${ }^{2}$, М.В. Мамошина \\ ${ }^{1}$ ФГБУ ФНКЦ физико-химической медицины ФМБА России, Москва; \\ ${ }^{2}$ НИЦ «Курчатовский Институт», Москва; \\ ${ }^{3}$ Саратовский филиал Самарского медицинского университета «Реавиз», Самара
}

\begin{abstract}
The aim of this work was to study the influence of treatment with alloferon (allocin) in combination with pyrogenal and cytokine therapy on the parameters of immunity, systemic inflammation, levels of herpesvirus replication and biochemical profile of patients with metabolic syndrome to search for new approaches to the treatment of the early stages of the disease. Markers of systemic inflammation and immunity, including key cytokines and lymphocyte subpopulations, were investigated. It was found that 1 month after the start of the study in patients receiving only allokin, there were signs of activation of humoral immunity. In patients receiving complex therapy, there were signs of activation of the cell-mediated mechanisms of adaptive immunity. These changes persisted after 6 months and were not accompanied by signs of systemic inflammation when evaluated at 1 and 6 months. The results of further observation showed that in patients receiving complex therapy, there were positive changes in lipid profile, which were the most prominent at the end of the study. Thus, in this study it was shown that in patients with metabolic syndrome complex immunomodulatory therapy, including allokin, pirogenal, ingaron and Roncoleukin, led to the activation of the cellular link of adaptive immunity, without causing a long-term increase in the level of markers of systemic inflammatory response. During long term observation the patients had positive dynamics of the main markers of the lipid profile, and a reduce in the level of serum markers of systemic inflammation. These delayed effects can apparently be associated with immunomodulatory effects of therapy, including the possible activation of regulatory $\mathrm{CD}^{+} \mathrm{CD}_{2} 5^{+} \mathrm{Foxp}^{+}$cells, which, according to the literature, have a protective effect in obesity, reducing insulin resistance.
\end{abstract}

Keywords: allokin; immunomodulatory therapy; inflammation; metabolic syndrome.

Целью работы явилась оценка монотерапии аллофероном (аллокин) и аллофероном в сочетании с пирогеналом и цитокинами Тх 1 типа на адипокины, системное воспаление и иммунитет у больных метаболическим синдромом для поиска новых подходов к терапии ранних стадий заболевания. Исследовали показатели системного воспаления и иммунитета, включая ключевые цитокины и субпопуляции лимфоцитов. Было выявлено, что через 1 месяц после начала исследования у больных, получавших монотерапию аллокином, отмечались признаки активации гуморального иммунитета и положительное влияние на измененные показатели липидного профиля, глюкозы, показатели системного воспаления. У пациентов, получавших комплексную терапию, имели место признаки активации клеточного звена адаптивного иммунитета. Указанные изменения адаптивного иммунитета сохранялись через 6 месяцев и не сопровождались признаками системного воспаления при оценке в точке 1 и 6 месяцев. У пациентов, получавших комплексную терапию, отмечались положительные изменения показателей липидного профиля, достигавшие наибольшей выраженности в конце исследования. При долговременном наблюдении у пациентов отмечалась положительная динамика основных маркеров липидного профиля, уменьшение уровня сывороточных маркеров системного воспаления. Указанные отсроченные эффекты можно, по-видимому, связать с иммуномодулирующим действием терапии, в том числе с возможной активацией регуляторных $\mathrm{CD}^{+} \mathrm{CD}^{+} 5^{+} \mathrm{Foxp}^{+}$клеток, которые, по данным литературы, обладают защитным эффектом при ожирении, уменьшая инсулинорезистентность.

Ключевые слова: аллокин; воспаление; иммуномодулирующая терапия; метаболический синдром. 
Introduction. More than 700 million adults in the world suffer from obesity $(\mathrm{Ob})$, including over $35 \%$ of people over 20 years of age in the United States of America. Ob is often accompanied by arterial hypertension, dyslipidemia and insulin resistance, which form the metabolic syndrome (MS). Inflammation is considered to be an important factor in the development of $\mathrm{Ob}$ and MS. The mechanisms of this connection are not fully known. A chronic inflammatory process in adipose tissue with infiltration by macrophages and T-cells is revealed in adipose tissue in $\mathrm{Ob}$ and MS. It has been suggested that in adipocytes, an increase in free radicals, the development of oxidative stress, hypoxia and activation of proinflammatory signaling cascades occur.

The TLR receptors (TLR2, TLR4) take part in inflammatory activation of adipocytes, and can be activated by high levels of free fatty acids and glucose [1]. Also, a disruption of neuroimmune interactions can play a role in the local inflammation, due to an inhibition of activity of the vagus nerve that normally suppresses the synthesis of inflammatory mediators by adipocytes [2]. The recruited macrophages also contribute to the local inflammation [3].

In turn, chronic inflammation, in particular, increased levels of cortisol, contributes to obesity and insulin resistance. In Ob, there is a shift of the activated phenotype of monocytes towards M1-type (pro-inflammatory activity). There is evidence that the expression of IL- 6 and TNF $\alpha$ by monocytes has a direct correlation with the body mass index. A number of studies report an increase in neutrophil expression of the activation marker CD66b, chemokine CXCL8 (IL-8), as well as an increase in the systemic level of myeloperoxidase and calprotectin secreted by activated neutrophils. It is believed that with $\mathrm{Ob}$. and MS, Th1-link of immunity is activated, which supports chronic inflammation and correlates with insulin resistance markers. According to modern studies, Th2 and Treg cells reduce insulin resistance and have a protective effect in MS [4]. Adipose tissue is now considered to be an extremely active endocrine organ that secretes adipokine hormones, either Pro-or anti-inflammatory factors linking metabolism to the immune system. Thus, leptin plays an important role in the central control of energy metabolism and regulation of the interaction of metabolism and the immune system. Indeed, the leptin receptor is expressed throughout the immune system, and the hormone itself regulates both innate and adaptive immune responses. A number of changes in immunity characteristics of $\mathrm{Ob}$. and MS are associated with the action of elevated concentrations of leptin and a deficiency in the production of adiponectin [5]. The role of chronic and latent infection in the development of MS, in particular of viral hepatitis B and C, of HIV infection, attracts great attention. Modern studies of intestinal microbiota indicate the pathogenetic role of its disorders in the development of metabolic syndrome [6, 7]. It remains unclear whether it is possible and practicable to restore the immune response in patients with metabolic syndrome at stage 1 of the disease.

The goal of this research was to evaluate the effect of monotherapy with alloferon (allokin-alpha) and alloferon in combination with pyrogenal and T-helper type 1 cytokines on adipokines, systemic inflammation and immunity in patients with metabolic syndrome to develop new approaches to the treatment of early stages of the disease.

Materials and methods. The study included 24 patients (mean age $-46 \pm 8$ years) with MS, 16 of them received allokin-alpha $(1 \mathrm{mg} \mathrm{s} / \mathrm{c}$ every other day for 21 days). Another 8 patients reseived allokine-alpha (the same dose) simultaneously with pirogenal $(\mathrm{i} / \mathrm{m}$ with a gradual increase from 50 to 250 MPD a day every other day, 6 doses), ingaron (500,000 units $\mathrm{s} / \mathrm{c}$ for the last 8 days of therapy) and Roncoleukin $(0.25 \mathrm{mg}$ i/v a day, every other day, 4 doses). The control group included 10 people with MS, comparable in age and sex and not receiving therapy. All patients were examined at

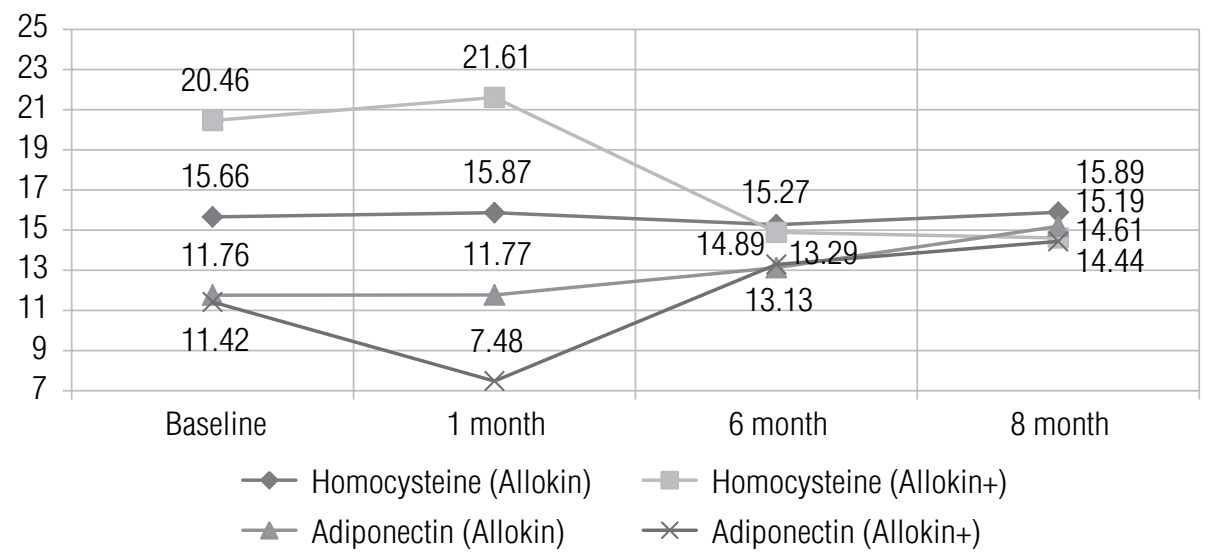

Fig. 1. Dynamics of homocysteine $(\mu \mathrm{mol} / \mathrm{l})$ and adiponectin $(\mu \mathrm{g} / \mathrm{ml})$ levels in patients with metabolic syndrome after immunomodulatory therapy. Levels of homocysteine significantly decreased in patients receiving complex therapy at 8 months, while adiponectin levels significantly increased in both groups of patients at 8 months 
the initial point, after $1,3,6$ and 8 months. Immunological examination included assessment of immunoglobulins IgA, IgM, IgG, cortisol, C-reactive protein (CRP) (Chema-medic), cytokines IL-2, IL-4, IL-8, TNFa (Vector-best) by enzyme immunoassay. The levels of leptin, adiponectin and homocysteine were assessed by enzyme immunoassay (Diagnostics Biochem Canada Inc., Canada; BioVendor, Czech Republic; Axis Shield, United Kingdom). Lymphocyte subpopulations $\left(\mathrm{CD}_{4} 5^{+} \mathrm{CD}^{+} \mathrm{CD}^{+}, \mathrm{CD} 45^{+} \mathrm{CD}^{+} \mathrm{CD}^{+}, \mathrm{CD}^{-} \mathrm{CD} 19^{+}\right.$, $\mathrm{CD}^{-} \mathrm{CD} 16^{+} \mathrm{CD} 56^{+}, \mathrm{CD}^{+}{ }^{+} \mathrm{CD} 16^{+} \mathrm{CD} 56^{+}$) were assessed by multicolor flow cytometry (BD). The levels of glucose, insulin, glycosylated hemoglobin, total cholesterol, triglycerides, LDLP, HDLP were assessed as described by manufacturer in a clinical laboratory. Herpesvirus replication was assessed by quantitative PCR. For comparison of group means $T$-test was applied. Differences were considered significant at $p<0.05$.

Results. Patients treated with allokin in monotherapy were analyzed in 2 subgroups - with the initial stage of MS and more developed MS and systemic inflammation. After 1 month after initiation of therapy in patients with the initial stage of MS, there were signs of activation of humoral immunity within normal limits (in 7 of 8 people the level of IgA increased, in 6 of $8-$ the level of $\mathrm{IgG})$, the level of CD $3{ }^{-} \mathrm{CD} 16^{+} \mathrm{CD} 56^{+} \mathrm{NK}$-cells also increased $(p<0.05)$, and these changes remained after 6 months of treatment. Also in this subgroup, an increase in the content of the anti-inflammatory hormone adiponectin from 11.76 to $15.16 \mu \mathrm{g} / \mathrm{ml}$ after 6 and 8 months was found. In patients with more developed MS on the background of therapy after 1 month the initially elevated level of markers of systemic inflammation decreased, including CRP, cortisol $(p<0.05)$, and this effect persisted up to 6 months. Also, on average, the levels of leptin steadily decreased $(37.55 \mathrm{ng} / \mathrm{ml}$ at the beginning of observation and $24.58 \mathrm{ng} / \mathrm{ml} 8$ months after treatment), and levels of adiponectin increased, as well as levels of monocytes, glucose and glycylated hemoglobin.

After complex therapy (allokin, pirogenal, roncoleukin and ingaron) in MS patients in 1 month. after therapy, the level of IgA (6 out of 8 people), $\mathrm{CD} 3^{+} \mathrm{CD} 4^{+} \mathrm{T}$-helper cells increased within normal limits and the level of activated HLA-DR ${ }^{+} \mathrm{CD}^{+}$ T-cells increased $(3.17 \pm 1.16 \%$ and $5.24 \pm 1.29 \%$, $p<0.005)$. At the same time, there were no signs of activation of the cellcytotoxicity system. These changes in adaptive immunity persisted after 6 months and were not accompanied by signs of systemic inflammation. In patients receiving complex therapy, there were positive changes in lipid profile, reaching the highest intensity at the end of the study: glucose, triglycerides, HOMA index before treatment exceeded the norm, and by the last point of the study they significantly decreased to normal levels (glucose: an average of 5.77 and $5.2 \mathrm{mmol} / \mathrm{l}$; triglycerides: 1.91 and $1.66 \mathrm{mmol} / \mathrm{l}$; insulin resistance index HOMA: 3.28 and 2.0). In addition, there was a decrease in the level of markers of systemic inflammation in patients of this group (cortisol 508.35 and $363.67 \mathrm{nmol} / 1$, homocysteine 20.46 and $14.61 \mu \mathrm{mol} / \mathrm{l})$. In this group, the level of $\operatorname{IgA}$ and $\operatorname{IgM}$ also significantly decreased at the last point of the study, approaching normal values $(p<0.05)$ (Fig. 1$)$.

In $2 / 3$ of patients the source of MS showed signs of active herpesvirus infection (HI) - the viral load exceeded the levels typical for healthy controls by 100 times or more. Alloferon has an antiviral effect. When analyzing the effect of monotherapy with allokin and complex therapy with cytokines and pyrogen, it was found that at 3-8 months in half of the patients the viral load has decreased, in some cases to normal levels, or the virus DNA was below the threshold of detection. Also, in 7 people DNA of Candida albicans could no longer be determined in saliva.

Conclusion. Thus, the pilot study showed that monotherapy with allokin and complex immunomodulatory therapy, including allokin, pirogenal, ingaron and roncoleukin, had a positive effect on the altered lipid profile, glucose, systemic inflammation in MS patients. Further studies are required to confirm the data and decipher the mechanisms of action of immunotropic therapy in metabolic syndrome.

\section{References}

1. Gregor MF, Hotamisligil GS. Inflammatory mechanisms in obesity. Annu Rev Immunol. 2011;29:415-45.

2. Pavlov VA, Tracey KJ. The vagus nerve and the inflammatory reflex--linking immunity and metabolism. Nat Rev Endocrinol. 2012;8(12):743-54.

3. de Melo LGP, Nunes SOV, Anderson G, et al. Shared metabolic and immune-inflammatory, oxidative and nitrosative stress pathways in the metabolic syndrome and mood disorders. Prog Neuropsychopharmacol Biol Psychiatry. 2017;78:34-50.

4. Van Herck MA, Weyler J, Kwanten WJ, et al. The Differential Roles of T Cells in Non-alcoholic Fatty Liver Disease and Obesity. Front Immunol. 2019;10:82.

5. Francisco V, Pino J, Campos-Cabaleiro V, et al. Obesity, Fat Mass and Immune System: Role for Leptin. Front Physiol. 2018;9:640.

6. Scheithauer TP, Dallinga-Thie GM, de Vos WM, et al. Causality of small and large intestinal microbiota in weight regulation and insulin resistance. Mol Metab. 2016;5(9):759-70.

7. Sobieszczyk ME, Werner L, Mlisana K, et al. Metabolic Syndrome After HIV Acquisition in South African Women. J Acquir Immune Defic Syndr. 2016; 73(4): 438-445. 